\title{
The Achievement of the Quality Standard of Education in MAN Palangka Raya
}

\author{
Jasiah1, Masriah² \\ 1IAIN Palangka Raya, Kota Palangka Raya, Indonesia, Email: jasiah@iain- \\ palangkaraya.ac.id \\ ${ }^{2}$ SMPN 2 Palangka Raya, Kota: Palangka Raya, Indonesia, Email: \\ masriahsut@gmail.com
}

\begin{abstract}
ABSTRAK
MAN Palangkaraya adalah sekolah mitra kementerian Agama dan status pencapaiannya sangat membanggakan, dan kelulusan mencapai $100 \%$ dari level Nasional (UAMMN) dan lulus Ujian Nasional (UN), dan terakreditasi A. Berdasarkan penjelasan di atas, penulis tertarik dan memilih judul Penjaminan Mutu Pendidikan di MAN Model Palangka Raya. Tujuan dari penelitian ini adalah untuk menjawab masalah penelitian ini Bagaimana pencapaian standar kualitas pendidikan di MAN Palangka Raya. Tempat penelitian ini adalah MAN Palangkaraya di Jl.Tjilik Riwut km. 4,5 Palangka Raya. Penelitian ini menggunakan metode kualitatif. Pengumpulan data dilakukan dengan observasi, wawancara dan dokumentasi. Subjek penelitian ini adalah kepala sekolah dan wakamad sebagai informan, guru dan pendidik, serta alumni. Keabsahan data dengan menggunakan trasferbilitas, akuntabilitas, reliabilitas, kredibilitas. Hasil penelitian menunjukkan bahwa: Penerapan penjaminan mutu di MAN Palangka Raya mencakup proses standar seperti; guru dan pendidik dan standar kompetensi. Pencapaian penjaminan mutu di MAN Palangka Raya telah dicapai seperti pemantauan, evaluasi, sertifikasi, akreditasi, dan ujian nasional baik secara internal maupun eksternal dilakukan oleh lembaga terkait seperti Kementerian Agama dan Dinas Pendidikan Provinsi Kalimantan Tengah.
\end{abstract}

Kata Kunci: Prsetasi, Pendidikan, Kualitas Standar

\begin{abstract}
MAN Palangkaraya is the partner schools of the ministries of Religious Affairs and the status is very proud achievement, and graduation reach $100 \%$ of the National level (UAMMN) and pass the National Exam (UN), and is accredited A. Based on the explanation above, the writer was interested in and choose the title of Education Quality Assurance in MAN Model Palangka Raya. The purpose of this study was to answer the problem of this research How does the achievement of quality standards of education in MAN Palangka Raya. The place of this research is MAN Palangkaraya at J1.Tjilik Riwut km. 4,5 Palangka Raya.

This study used qualitative methods. The data collection did by observation, interview and documentation. The subjects of this research were headmaster and wakamad as an informant, teachers and educators, and alumni.

The validity of the data by using trasferbilitas, accountability, reliability, credibility. The results of the research showed that: Implementation of quality
\end{abstract}


assurance in MAN Palangka Raya includes the standard process such as; teachers and educators and competency standards.

Achievement of quality assurance in MAN Palangka Raya have been achieved such as monitoring, evaluation, certification, accreditation and national exams both internally and externally is carried out by the relevant agencies such as the Ministry of Religious Affairs and The Central Kalimantan Provincial Education Office.

Keywords: Achievement, Education, Quality, Standar.

\section{Article history:}

$\begin{array}{ll}\text { Received } & : 31-12-2018 \\ \text { Revised } & : 14-1-2019 \\ \text { Accepted } & : 27-3-2019\end{array}$

\section{PENDAHULUAN}

Upaya peningkatan mutu pendidikan terus dilakukan oleh berbagai pihak. Upaya tersebut dilandasi suatu kesadaran betapa pentingnya peranan pendidikan dalam pengembangan sumber daya manusia dan pengembangan watak bangsa (Nation Character Building) untuk kemajuan masyarakat dan bangsa. Harkat dan martabat suatu bangsa sangat ditentukan oleh kualitas pendidikannya.

\begin{tabular}{|c|c|c|}
\hline \multicolumn{3}{|c|}{ Akhir-akhir } \\
\hline arus berh & hadapan & denga \\
\hline ntutan & Peraturan & teri \\
\hline Pendidikan & Nasional & Nomor 6 \\
\hline Tahun 2009 & tentang & pelaksan \\
\hline penjaminan & mutu & Pendidik \\
\hline terutama & berada & pada satua \\
\hline pendidikan, & & penyelen \\
\hline pendidikan & & berkew \\
\hline menyediakan & n dan & membe \\
\hline ntuan & dalam & pement \\
\hline
\end{tabular}

standar, dan pemerintahan kabupaten/kota pemerintah provinsi, dan pemerintah juga memiliki tanggung jawab untuk melakukan supervisi, pengawasan, evaluasi, fasilitasi, saran, arahan, dan atau bimbingan kepada satuan program pendidikan (Fatah, 2013:1). Tantangan yang dihadapi madrasah secara khusus adalah menyangkut persepsi masyarakat cendrung diskriminatif sehingga madrasah kurang mendapat perhatian bahkan ada yang menganggap sebagai lembaga pendidikan kelas dua setelah sekolah umum. Melihat kondisi seperti ini, tentu madrasah tidak boleh hanya berpangku tangan atau pasrah menerima kenyataan. Karena itu, madrasah harus berbenah diri untuk menepis anggapan yang kurang menguntungkan bagi madrasah. Sejalan dengan 
berjalannya waktu, banyak madrasah yang semakin baik mutunya dan mampu bersaing dengan sesama madrasah maupun dengan sekolah umum lainnya.

Untuk menjawab anggapan tersebut Madrasah Aliyah Negeri (MAN) Model Palangka Raya berusaha semaksimal mungkin untuk memenuhi sebagai berikut : Pertama, meningkatkan kuantitas dan kualitas lulusan dengan indikator (1) Siswa dapat berprestasi dalam menempuh ujian Nasional dan lulus dari madrsah dengan predikat baik sehingga mereka dapat melanjutkan pendidikan ke jenjang yang lebih tinggi pada satuan pendidikan (2) Meningkatnya jumlah siswa MAN Model Palangka Raya yang berprestasi di bidang Akademik terutama dalam mengikuti olympiade, bahkan tahun 2014 meraih perunggu tingkat Nasional bidang Matematika dan Fisika, serta bidang non akademik (seperti olah raga, seni dan sebagainya) pada tingkat kabupaten/kota prestasi semakin meningkat. (3) lulusan Madrasah dapat berkompetisi dengan lulusan sekolah lainnya. Kedua mengembangkan program

unggulan yang dapat meningkatkan mutu madrasah seperti meningkatnya pengetahuan siswa dalam penguasaan tehnologi hal ini di laksanakan MAN Palangka Raya ketika satu-satunya sekolah di Palangka Raya yang siap untuk mengikuti Ujian CBT (Computer Best Test), adanya kegiatan mengembangkan keterampilan yaitu: 1) Tinkom (Soft Ware, Hard Ware jaringan dan perawatan), 2) Elektronika, 3) Tata Busana, 4) Peternakan dan muatan lokal Teknologi Informasi Komunikasi (Tinkom) mulai tahun pelajaran 2014/2015 MAN Palangka Raya mulai menerapkan (2014: 10).

Madrasah Aliyah Negeri Palangka Raya terletak di jalan Tjilik Riwut $\mathrm{Km}$ 4,5 merupakan relokasi dari MAN II Yogyakarta dengan Keputusan Menteri Agama Nomor 27 tahun 1980 tanggal 5 mei 1980, merupakan Madrasah dengan ciri utamanya sebagai sekolah umum yang bercirikan khas agama Islam berusaha mewujudkan agar menjadi Madrasah Aliyah yang baik dan berprestasi dan sebagai tanggung jawabnya adalah mengembangkan madrasah sebagai sekolah umum berciri khas agama Islam, 
Mewujudkan amanah sebagai Madrasah model yang mampu menjadi pusat sumber belajar bagi madrasah-madrasah lain, Mewujudkan Madrasah yang mampu mengembangkan akademik dan non akademik dan menjadikan madrasah yang mampu membina akhlakul karimah dan peduli terhadap lingkungan. Adapun program unggulan bidang keagamaan dan kemasjidan adalah : Penanaman dan praktek akhlakul karimah bagi seluruh civitas akademik melalui kegiatan seharihari pembiasaan Tadarus Al-qur.an setiap pagi, sholat zuhur, ashar dan sholat jum'at berjamaah, praktek Manasik haji, praktek penyelenggraan jenazah, Majelis ta'lim Putri, Majelis zikir, dan Muhadarah (2014:10).

Adanya Bidang Peningkatan Mutu Akademik MAN Palangka Raya dengan tujuan (1) Membantu pencapaian visi dan misi MAN Palangka Raya (2) Memfasilitasi dan mengkoordinasikan perbaikan mutu berkelanjutan (3) Menjamin konsestensi dan efektifitas penjaminan mutu pendidikan (4) Menetapkan peran seluruh komponen dalam peningkatan mutu

pendidikan. Adapun program peningkatan mutu akademik yang sangat aktif berjalan adalah dalam pembinaan kelas olympiade Sains dan Kompetisi Sains Madrasah (KSM) meningkatkan prestasi peserta didik prestasi non akademik semakin meningkat, tentunya dalam hal ini di tunjang dengan adanya tenaga guru PNS yang yang berkualifikasi akademik SI bahkan ada yang sudah S2 dan mempunyai sertifikat pendidik sebagai guru profesional (wawancara Jumberi).

Hal tersebut ditambahkan hasil wawancara dengan Kepala MAN Palangka Raya berkenaan dengan hasil ujian Nasional tiga tahun terkhir siswa MAN Palangka Raya $100 \%$ lulus dan sekolah terakreditasi A (Amat Baik) sampai tahun 2016 oleh Badan Akreditasi Nasional Sekolah/Madrasah (BANS/M) sertifikat Akreditasi ditetapkan di Palangka Raya 7 Nopember 2011 (wawancara Kepala Madrasah).

Dengan berbagai usaha persiapan dan pelaksanaan untuk mencapai kelulusan ujian akhir madrasah bertarap Nasional (UAMMN) dan lulus Ujian Nasional 
(UN) dengan sistem Computer Based test (CBT) MAN Palangka Raya tahun 2014/2015 lulusan madrasah dapat memenuhi harapan stakeholder dapat memenuhi harapan guru, siswa, orang tua, masyarakat dan pemerintah Maka dapatlah diketahui keberhasilan mutu sesuai standar Nasional.

Untuk memastikan bahwa setiap standar di MAN Model Palangka Raya direncanakan atau ditetapkan dapat dicapai atau sesuai dengan Standar Pendidikan Nasional (SNP) dan Pelaksanaan semua komponen dalam sistem sekolah bekerja secara optimal dan bersinergi bagi tercapainya standar yang ditetapkan. Berdasarkan latar belakang di atas permasalahan yang dibahas bagaimana ketercapaian standar mutu pendidikan di MAN Palangka Raya?

Hasil penelitian ini diharapkan akan memberikan sumbangan:

1. Dalam konteks teoritis, penelitian ini memberikan manfaat antara lain:

a. Untuk menghasilkan model penjaminan mutu pendidikan di sekolah

b. Sebagai dasar untuk penelitian selanjutnya agar lebih

\section{METODE PENELITIAN}

Tempat penelitian ini dilaksanakan di MAN Model Palangka Raya karena madrasah ini satu satunya Madrasah Aliyah Negeri yang ada di kota Palangka Raya terletak di Jalan Tjilik Riwut km. 4 Palangka Raya, Penelitian ini menggunakan metode kualitatif. Teknik dan Prosedur Pengumpulan Data.

Analisis data dilakukan melalui tiga tahapan yaitu meliputi: reduksi data, penyajian data dan penarikan kesimpulan/verifikasi. Untuk menganalisis data dalam masalah ini 
penulis menggunakan logika deduksi, dengan membandingkan teori yang melatar belakangi permasalahan. Data yang diperoleh dari lapangan akan diolah dengan cara mengumpulkan semua data yang ada. Data yang ada dikelompokkan, diseleksi dan menguraikan menjadi beberapa bagian dan mencari hubungan/keterkaitan data dengan pendapat para pakar serta selanjutnya dianalisis.

Pemeriksaan Keabsahan Data

Pemeriksaan keabsahan suatu data atau pengujian kebenaran data digunakan cara uji kredibilitas, transferabilitas, dependabilitas, dan konfirmabilitas.

III. HASIL DAN PEMBAHASAN

\section{A. Ketercapaian Standar Mutu Pendidikan di MAN Model Palangka Raya}

\section{Penjaminan Mutu (Quality Assurance)}

Secara umum yang dimaksud dengan penjaminan mutu (Quality Assurance) adalah proses penetapan dan pemenuhan standar pengelolaan secara konsisten dan berkelanjutan, sehingga konsumen, produsen dan pihak lain yang berkepentingan memperoleh kepuasan (fatuhrohman, 2012: 142). Penjaminan mutu secara internal oleh satuan penididikan adalah pengelolaan satuan pendidikan pada jenjang pendidikan menerapkan manejemen berbasis sekolah: kemandirian, kemitraan, partisipasi, keterbukaan, dan akuntabilitas.

Islam telah mengajarkan dan memberikan dasar tentang mutu, ajaran tersebut sebagai berikut:

Mutu merupakan realisasi dari ajaran ihsan yakni berbuat baik kepada semua pihak disebabkan karena Allah telah berbuat baik kepada manusia dengan aneka nikmat-Nya, dan dilarang berbuat kerusakan dalam bentuk apapun. Hal tersebut sebagaimana termaktub dalam Al-Qur-an surah alQashash/28:77.

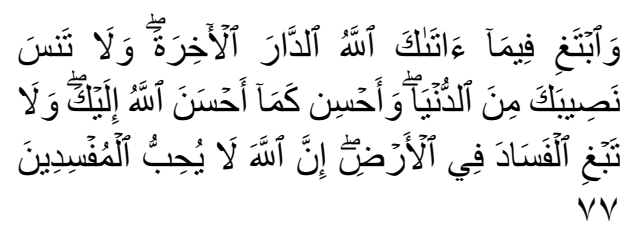

Artinya : Carilah pada apa yang telah dianugerahkan 


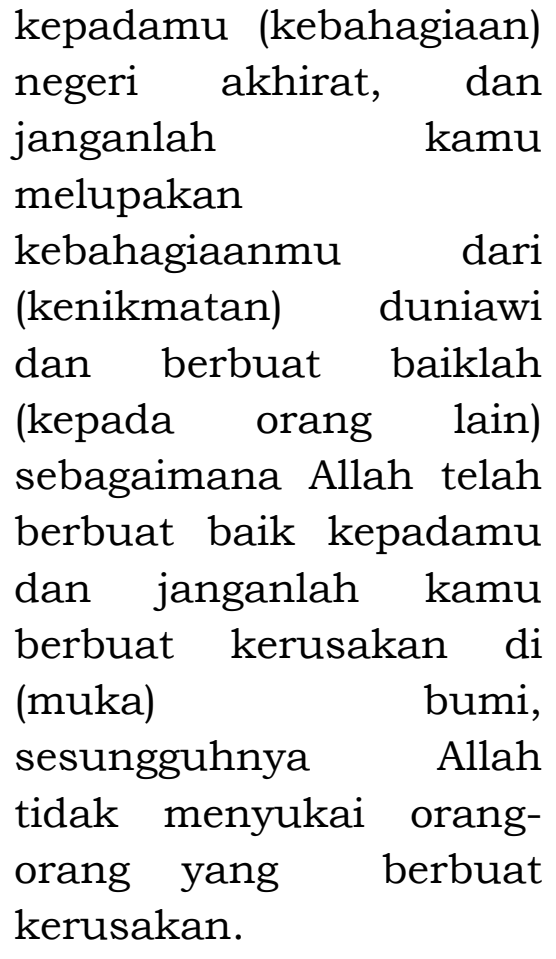

2. Ketercapaian Standar Mutu Pendidikan

Menurut Peraturan Menteri

Pendidikan Nasional nomor 63 tahun 2009 tentang Sistem Penjaminan mutu Pendidikan pasal 20 ayat 2 Pengukuran ketercapaian standar mutu acuan dilakukan melalui:
a. Audit kinerja
b. Akreditasi
c. Sertifikasi
d. Bentuk lain pengukuran

ketercapaian mutu pendidikan.

Pengukuran ketercapaian standar acuan mutu dan evaluasi mutu pendidikan bisa dilakukan terhadap satuan/program pendidikan melalui: a. Monitoring satuan /program Pendidikan oleh Pemerintah daerah (MSPD),

b. Akreditasi,

c. Sertifikasi,

d. Evaluasi Diri satuan/program pendidikan,

e. Ujian Nasional.

Berdasarkan pendapat di atas dapat dipahami bahwa bahwa ketercapaian standar mutu pendidikan meliputi Evaluasi Diri satuan/program pendidikan, Monitoring satuan /program Pendidikan oleh Pemerintah daerah (MSPD), Akreditasi, Sertifikasi dan Ujian Nasional.

\section{a. Monitoring}

Monitoring internal yang dilaksanakan kepala madrasah sering sekali dilaksanakan di MAN Model Palangka Raya Monitoring sendiri tentang kegiatan guru, tenaga kependidikan dalam menjalankan tugas apakah menemukan permasalahan yang dapat memepengaruhi jalannya dalam menjalankan tugas dalam penerapan kebijakan sehingga dapat disimpulkan bahwa focus daripada monitoring itu sendiri berdasarkan pada pelaksanaannya. Adanya monitoring dari pihak luar yaitu 
kepala dinas pendidikan dan dari pengawas kemeterian agama kota Palangka Raya monitoring yang digunakan untuk memotivasi keterlibatan para pelaksana dalam kegiatan pendidikan dan untuk mengetahui kemajuan dan kekurangan pelaksanaan program dalam rangka perbaikan untuk mencapai tujuan program.

\section{b. Evaluasi}

Kepala madrasah mengadakan penilaian atau evaluasi dengan maksud untuk melihat apakah program sekolah sudah dilaksnakan sepenuhnya dan apa kendala di lapangan (Daryanto, 2008: 7). Berdasarkan dari dari data di atas di MAN Model Palangka Raya pelaksanaan evaluasi bisa dilaksanakan, pelaksanakan oleh kepala sekolah, wakamad kurikulum wakamad sarana prasarana dan wakamad humas mengevaluasi pelaksanaan tugas masing-masing atau dengan mengadakan evaluasi diri, guru menilai sendiri kelengkapan perangkat pemebelajarannya sendiri, atau mengevaluasi program sekolah kedepannya apakah sudah berjalan atau tidak.

\section{c. Akreditasi}

Pada prinsipnya dalam rangka penjaminan mutu pendidikan tersebut memiliki keterkaitan yang erat dengan proses akreditasi suatu sekolah atau satuan pendidikan tertentu. Penjaminan mutu (Quality Assurance) adalah upaya pengelolaan mutu yang dilakukan oleh pihak internal sekolah, dalam rangka untuk memberikan jaminan bahwa semua aspek yang terkait dengan layanan pendidikan yang diberikan oleh suatu lembaga atau satuan pendidikan tertentu dapat mencapai suatu standar mutu tertentu.

Sementara itu, akreditasi sekolah atau satuan pendidikan merupakan upaya untuk memberikan pengakuan terhadap suatu institusi pendidikan (satuan pendidikan) oleh suatu lembaga (BAS) yang bersifat eksternal yang menyatakan bahwa lembaga pendidikan tersebut dapat memberikan layanan pendidikan dengan standar kualitas tertentu sesuai dengan status akreditasi yang disandangnya.

Sebagaimana hasil dokumen sertifikat Akreditasi MAN Model Palangka Raya pada tanggal 19 
Desember 2007 telah memperoleh akreditasi dengan peringkat Amat Baik dengan nilai 93,48, di tetapkan di Palangka Raya 19 desember 2011. dan pada 7 Nopember 2011 memperoleh akreditasi dengan peringkat Amat baik dengan nilai 97,91 sampai dengan tahun 2016 oleh Badan Akreditasi Nasional Seklah/Madrasah (BAN_SM).

Dengan akreditasi ini memberikan informasi tentang kelayakan madrasah atau program yang dilaksanakan berdasarkan Standar Nasional Pendidikan (SNP). Pelaksanaan penjaminan mutu di madrasah dilakukan oleh pihak internal sekolah, sebagai bagian dari manajemen mutu sekolah, sedangkan pengawasan atau evaluasi terhadap pelaksanaan penjaminan mutu, yang salah satunya dilakukan dalam bentuk akreditasi, dapat dilakukan oleh pihak eksternal sekolah.

\section{d. Ujian Nasional}

Ujian Nasional merupakan pengukuran ketercapaian standar acuan mutu pendidikan terkait dengan pencapaian standar komptensi kelulusan. Pengukuran tersebut akan menghasilkan tingkat kelulusan perserta didik secara nasional. Data yang diperoleh pada pengukuran adalah data kinerja dan prestasi peserta didik (Fatah, 2012: $31)$.

Kriteria kelulusan peserta didik MAN Model Palangka Raya dinyatakan lulus dari satuan pendidikan setelah :

1) Menyelesaikan seluruh program pembelajaran.

2) Memperoleh nilai sikap/prilaku minimal baik.

3) Lulus ujian Sekolah.

4) Memenuhi kreteria kelulusan yang ditetapkan oleh satuan pendidikan berdsarkan perolehan nilai S/M.

5) Nilai $\mathrm{S} / \mathrm{M}$ di peroleh dari gabungan antara nilai $\mathrm{S} / \mathrm{M}$ dan nilai rata-rata raport semester III, IV dan $\mathrm{V}$ dengan pembobotan 30\% nilai S/M dan 70\%. Nilai rata-rata raport. Berdasarkan hasil masingmasing mata pelajaran yang diujikan pada Ujian Sekolah (US) 2014/2015, Ujian akhir Madrasah berstandar Nasional (UANBN) tahun 2014/2015, dan peserta Ujian Nasiona (UN) dengan sistem computer Based test (CBT) dengan sistem Paper Based Tes (PBT) tahun 
2014/2015 MAN Model Palangka

Raya memperoleh $100 \%$ lulus.

Sikap dan prilakunya yang patuh dalam melaksnakan ajaran agama yang dianutnya, dalam konteks ujian Nasional tawakal yaitu berusaha secara maksimal dan hasilnya diserahkan kepada Tuhan yang maha kuasa.jujur perilaku yang diasarkan pada upaya menjadikan dirinya sebagai orang yang selalu dapat dipercaya dalam perkataan dan tindakan kaitannya dengan ujian nasional adalah sikap atau perilaku yang tidak mau berbuat curang (mencontek) pada saat ujian Nasional dilaksanakan, toleransi, sikap dan tindakannya yang menghargai perbedaan agama, suku,etnis, pendapat, sikap dan tindkana orang lain yang balam berbeda pendapat dengan dirinya. Dalam konteks ujian nasional adalah memulai ujian nasional dengan doa bersama sesuai dengan agama dan kepercayaan masingmasing, disiplin, tindakan yang menunjukan perilaku tertib dan patuh pada berbagai ketentuan dan peraturan dalam melaksanakan ujian Nasional kerja keras adanya prilaku sungguh-sungguh dalam kegiatan belajar dan tugas serta menyelesaikan tugas dengan sebaikbaiknya. Dalam konteks ujian Nasional siswa akan bekerja keras untuk mengembangkan potensi dirinya untuk menghadapi ujian Nasional: kreatif berpikir dan melakukan sesuatu untuk menghasilkan cara atau hasil baru dari sesuatu yang telah dimilikinya. Dalam konteks ujian nasional siswa akan berfikir dan menemukan cara yang tepat dalam mengerjakan soal ujian nasional mandiri, sikap dan prilaku yang tidak mudah tergantung kepada orang lain dalam menyelesaikan tugas. Dalam konteks ujian Naional siswa tidak hanya belajar di bawah pengawasan guru dan orang tua saja tetapi dengan penuh kesadaran siswa belajar di bawah pengawasan guru dan orang tua saja tetapi dengan penuh kesadaran siswa belajar secara mandiri karena ingin berhasil dalam ujian Nasional sebagai langkah awal proses pengembangan diri selanjutnya rasa ingin tahu dalam mempersiapkan diri untuk menghadapi ujian Nasional selalu berusaha mencari tahu secara mendalam tentang hal yang terkait materi yang dilaksanakan dalam ujian nasional 
dengan tujuan dapat memahami materi tersebut.

\section{e. Sertifikasi}

Makna sertifikat guru adalah proses pemberian sertifikat pendidik kepada guru, sertifikat pendidik adalah sebuah sertifikat yang dikeluarkan oleh perguruan tinggi penyelenggara sertifikasi sebagai bukti formalpengakuan yang diberikan kepada guru sebagai tenaga profesional. Tujuan sertifikasi guru adalah untuk menentukan kelayakan guru dalam melaksanakan tugas sebagai agen pembelajaran dan mewujudkan tujuan pendidikan nasional.

Guru dimaksud harus memilki kualifikasi akademik sekurang kurangnya SI/D-IV dan bersertifikat pendidik, jika seorang guru mamilki keduanya,statusnya diakui oleh negara sebagai guru profesional UU NO 14 Tahun 2005 tentang guru dan dosen (2014: 3).

Pemberian sertifikat pendidik kepada guru yang telah memenuhi persyaratan tertentu, yaitu memiliki kualifikasi akademik, kompetensi, sehat jasmanai dan rohani, serta memiliki kemampuan untuk mewujudkan tujuanpendidikan nasional. Meningkatkan mutu guru

\section{DAFTAR PUSTAKA}

Daryanto, $2008 . \quad$ Evaluasi Pendidikan, PT.Reneka Cipta, Jakarta

Departemen Agama RI, 1998. Alqur.an dan Terjemahnya, Madinah: Mujamma al- Malik fahd Thib'at al-Mushaf.

Depdiknas RI, 2003. UndangUndang Republik Indonesia Nomor 20 Tahun 2003 tentang Sistem Pendidikan Nasional.

Dokumen, 2014. Profil Madrasah Sehat, Madrasah Aliyah Negeri Palangka Raya tahun.

Gultom, Syawal. Ujian Nasional Sebagai Wahana Evaluasi Pengembangan Pendidikan Karakter Bangsa. Jurnal.

H. A. R. Tilaar, (2006), Standarisasi Pendidikan Nasional: Suatu Tinjuan Kritis. Jakarta: Rineka Cipta. 
Lembaga Pendidikan dan Tenaga Pendidikan Fakultas Ilmu Tarbiyah dan Keguruan UN Sunan Ampel, 2014. Bahan Ajar Pendidikan dan Pelatihan Profesi Guru Sertifikasi Guru/ Pengawas dalam Jabatan Kouta tahun 2014, Surabaya.

Masnur Muslich, 2008. KTSP: Dasar Pemahaman dan Pengembangnnnya, Jakarta: Bumi Aksara.

Muhammad Fathurrahman, 2012. Sulistyorini, Implementasi Manajemen Peningkatan Mutu Pendidikan Islam Peningkatan Lembaga Pendidikan Islam Ssecara Holistik dan Teoritik, Yogyakarta.

Muhammad Fathurrohman, 2012. Sulistyorini, Implementasi Manajemen Peningkatan Mutu Pendidikan, Yogyakarta.

Mulyono, Manajemen Administrasi dan Organisasi Pendidikan, Jogjakarta: Arr-ruzz Media Groups.

Nana Sudjana, 1991. Penilaian Hasil Proses Belajar Mengajar, Bandung: Remaja Rosdakarya.

Nanang Fattah, 2013. Sistem Penjaminan Mutu Pendidikan Dalam Konteks Penerapan $M B S$, Bandung: PT.Remaja Rosdakarya.

Peraturan Mentri Pendidikan Nasional no 63 tahun 2009 bagian ke empat jenis kegiatan Penjaminan mutu pendidikan pasal 20 ayat 2 .

Prasetyo, Iis, 2009. Definisi Monitoring dan Evaluasi". http://www.monev.com/monit oring evaluasi $=$ iis prasetyo. (online tanggal 16 Juni 2015 pukul 19.00 wib)

Setiadi, Hari. Dampak Ujian Nasional Pada Karakter Bangsa. Jurnal. 